\title{
A tale that never loses in the telling: Considerations for the shifting ethnobaseline based on artisanal fisher records from the southwestern Atlantic
}

\author{
Sérgio Ricardo Santos ${ }^{1 *}$, Márcio Luís Chagas Macedo ${ }^{1}$, \\ Thaís Rodrigues Maciel ${ }^{1}$, Gabriel Barros Gonçalves Souza ${ }^{1,2}$, \\ Laís da Silva Almeida ${ }^{3}$, Otto Bismarck Fazzano Gadig ${ }^{4}$ and Marcelo Vianna ${ }^{1}$
}

\begin{abstract}
An ethnoichthyological survey was conducted with fishers from traditional communities distributed between the Lakes Region and the northern Fluminense region, in the state of Rio de Janeiro, Brazil. The study was developed based on semi-structured interviews, with fishers with at least 30 years of experience. Fishers were asked about changes noted for the biological communities with which they interact with, such as reports concerning abundance changes, the disappearance of certain species or the insertion of new ones, as well as weight and size changes. The reported ethno-names were confirmed at the specific level whenever possible through photographs and complementary descriptions. Eighty-five fishers aged between 39 to 83 years old were interviewed. Fishing activity times ranged from 30 to 68 years, averaging 40.6 years. Fishers reported differing estimates from what was expected according to the known length-weight relationship for the reported species. In general, length estimates were closer to the expected for medium-sized fish from $0.3 \mathrm{~m}$ to $1 \mathrm{~m}$. Sixty-nine ethno-names and their variations were identified, associated with 58 fish categories. Of this total, denominations were associated to 47 local fauna species or genera, while one ethno-name was not linked to any taxonomic identification. This study is the result of research financed by the Brazilian Fund for Biodiversity and the Pescarte Environmental Education Project, a mitigation measure required by the Federal Environmental Licensing, conducted by IBAMA.
\end{abstract}

Keywords: Ethnoknowledge; Small scale fisheries; Common names.

\footnotetext{
1 Laboratório de Biologia e Tecnologia Pesqueira (BioTecPesca), Universidade Federal do Rio de Janeiro, Rio de Janeiro, RJ, 21941-590, Brazil.

2 Programa de Pós-Graduação em Ecologia, Universidade Federal do Rio de Janeiro, Rio de Janeiro, RJ, 21941-590, Brazil.

3 Universidade Federal Fluminense, Niterói, RJ, 24220-008, Brazil.

4 Laboratório de Pesquisa de Elasmobrânquios, Universidade Estadual Paulista, São Vicente, SP, 11330-900, Brazil.

* Corresponding author $\bowtie$. E-mail address: SRBS (srbs.ufrj@gmail.com), MLCM (morcego84.2@gmail.com),

TRM (thaisrmaciel@gmail.com), GBGS (gabrielbbarros@gmail.com), LSA (lais_almeida@id.uff.br), OBFG (otto.gadig@unesp.br), MV (mvianna@biologia.ufrj.br)
} 


\section{SIGNIFICANCE STATEMENT}

The scarcity of adequate official Brazilian fisheries data is a known obstacle for a clear picture of the decline of exploited populations and hinders the application of efficient management policies. Ethnoknowledge held by traditional communities offers a complementary data source even more important in the context of tropical and developing countries, where artisanal fisheries are presently and historically relevant. The survey carried out herein sheds light on a period of over 50 years of artisanal fisheries in one of the first exploited coastal waters since the European colonization of the Americas. This research also compiled an extensive list of ethno-names applied to the local fish populations and their closest taxonomic species, which is potentially useful to adequately attain a species-level fisheries statistics. The study also allowed for the establishment of two important new records on the presence of the white shark Carcharodon carcharias in the southeastern Brazilian coast.

\section{INTRODUCTION}

Fishing activity impacts must be analyzed in a context of continuous and historical ecosystems changes, alongside regional colonization, demographic expansion, and technological fleet and capture equipment changes. Therefore, fishing activities represent a changing scenario where optimal ecosystem condition parameters should reflect how much the environment has already changed over time. The "Shifting baseline syndrome", a concept proposed by Pauly (1995), is described as the adulteration of collective memory by gradual changes in environmental conditions due to loss of past information and lack of experience of new generations with past conditions, making change perceptions unfeasible. Without an accurate record of these changes, the conservation status of a certain ecosystem reflects a generational component, and what a group of people deduces as a pristine environment state does not match the same perceptions of previous or later generations. This necessarily implies that the state considered as ideal for a fishing area does not represent the optimum trophic web condition in place prior to any human intervention. This is even more relevant in the historical context of artisanal fishing communities and concerning the impacts already caused by these and other human interventions (Pinnegar and Engelhard 2008).

Fishing activity history surveys allow for the understanding of and inferences on trophic and ecosystem changes over time and space, as well as for accompanying technological changes that have altered fishing efforts (Freire et al. 2015; Prestrelo and Vianna 2016). In the case of Brazilian artisanal fisheries, although academic contributions have been published (e.g., Silva-Júnior et al. 2008; Prestrelo et al. 2019), government agencies from different spheres and periods have failed to monitor fisheries throughout the $20^{\text {th }}$ century. This is repeated to a greater or lesser extent in several other countries, especially those in development, revealing the need to apply empirical knowledge accumulated by artisanal fishers to reconstruct fishing histories and minimize temporal data gaps (e.g. Blythe et al. 2013; Saldaña-Ruiz 2017;
Canty et al. 2019).

Although the Shifting Baseline Syndrome (SBS) is addressed in several studies where this concept has been demonstrated (e.g., Giglio et al. 2015; BarbosaFilho et al. 2020), an effort to improve the understanding under which conditions guide cases of change is required, also taking into account the spatial scale in which they occur (Soga and Gaston 2018). Studies on artisanal fisher ethnoknowledge serve as an excellent object to broaden ecosystem understanding (Ladislau et al. 2021) and offers not only a data source for the observation of temporal patterns, unavailable in the academic literature or monitoring bodies, but also allows for the assessment of cases of change in isolated and restricted communities concerning their ability to move and exploit resources (Soga and Gaston 2018). The present study focuses on artisanal fishers between the Lakes Region area and northern Fluminense region in the state of Rio de Janeiro, southeastern Brazil, who display notorious wisdom concerning fishing stocks, environmental conditions, technological changes and the biological communities with which they interact with. The study area is of significant historical, economic and ecological interest, and the interviews aimed to observe fisher perceptions concerning environmental changes based on the history of local fisheries production and their characteristics.

\section{MATERIAL AND METHODS}

The area between the Lakes Region and the northern Fluminense region of the state of Rio de Janeiro, located on the southeastern Brazilian coast, extends from $21^{\circ} \mathrm{S}$ to $23^{\circ} \mathrm{S}$, comprising 11 municipalities and over 1.3 million inhabitants (IBGE 2010) (Figure 1). Two water bodies predominate over the continental shelf of the region, the South Atlantic Central Water $(\mathrm{SACW})$, characterized by cold waters $\left(6^{\circ} \mathrm{C}-18^{\circ} \mathrm{C}\right.$, $34.5 \%$ S-36.0\%o S) and flowing in the opposite direction of the Brazil Current, and the ocean surface water (SW), a combination of coastal and ocean waters $\left(<18^{\circ} \mathrm{C},>36 \%\right.$ S $)$ with continental inputs and periodic SACW insertions caused by also periodic up- 


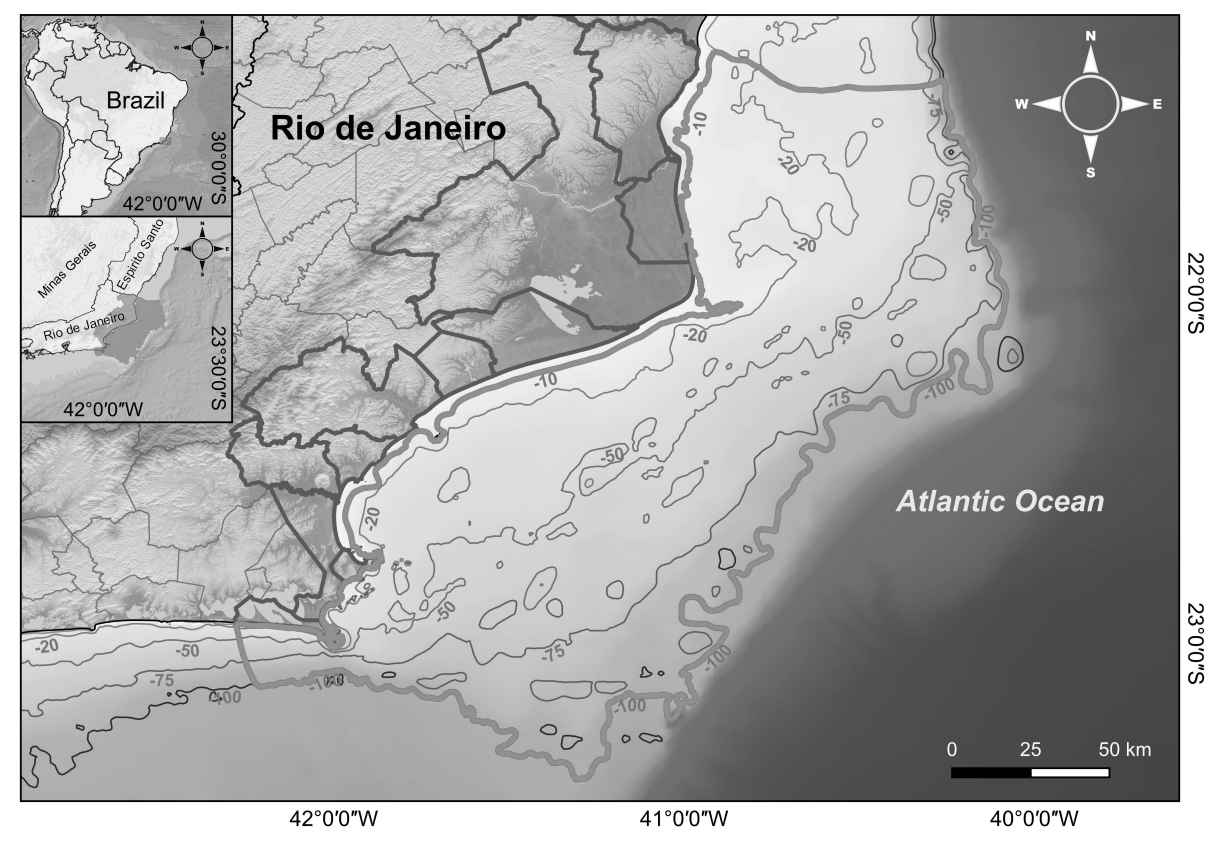

Figure 1. Marine area exploited by artisanal fishers from the Lakes Region and Northern Fluminense region (Rio de Janeiro, Brazil), which stretches from the coast to the $100 \mathrm{~m}$ isobath.

welling phenomena (Viana et al. 1998). This water body meeting is dynamic, resulting in a rich ecosystem, with the simultaneous occurrence of species from both tropical and temperate areas, many of which display economic interest (Coelho-Souza et al. 2012). The human occupation history in the region is ancient, as the area has been inhabited since before the European colonization of the 16th century, by native populations practicing various types of fishing, many of which are still in use in the region by local artisanal fishers (Bernardes and Bernardes 1950; Lopes et al. 2016).

The study was developed based on the application of semi-structured interviews and carried out between November/2020 and February/2021. The snowball sampling method was chosen for the study (Grønmo 2020) and to ease the access to fishers, the local leadership was previously contacted. The study was fully explained along with the questionnaire to the leaders while they were interviewed. After this initial interview, they were asked to offer the initial list of fishers to be contacted. Interviews were performed for local fishers with at least 30 years of experience in artisanal fishing and displaying a substantial knowledge in the study area. These fishers represent the small-scale fisheries practiced using a wide variety of gear in a Brazilian coast area historically known for its fishing activities (Braga et al. 2020). Preference was given to fishers with longer fishing experiences and/or who were appointed as leaders and bearers of fishing memory in or in part of the study region. The research followed the Declaration of Helsinki and Tokyo guidelines for humans and was approved by the National Health Council research ethics committee (Plataforma Brasil/Ministério da Saúde) no. 4,269,532 in August/2020.

Fishing time, age and gear used by the respondents were surveyed, as well as family ties to fishing, expressed as kinship degree. Fishers were asked about their perceptions regarding changes in the local biological communities with which they interact with, such as reports on species abundance changes and fish disappearance or the appearance of new species, as well as weight and size changes. Photographic reports and reports on the most memorable catches (records) of the main local fish species were also obtained, such as greater capture concerning total production volume, larger individual and greater weight. The data were organized in spreadsheets and complemented with biological information available in the literature.

\section{Data analysis}

The cornerstone of the study is the large record or catch reported by fishers in presential interviews. Since the limit of what can be considered a large catch can vary from fisher to fisher, we relied on what the 
fisher considered worth mentioning as a memorable moment in his professional career. The ethno-names obtained in the interviews were confirmed at the specific level whenever possible through photographs and complementary descriptions. Records of all species were grouped due to great differences on the number of reports for different species. The reports per species varied from one to 18 , with an average of 5 records per species. The records were organized in three size classes $(\mathrm{TL}>1 \mathrm{~m}, 0.3 \mathrm{~m}<\mathrm{TL}<1 \mathrm{~m}$ and $\mathrm{TL}<0.3$ $\mathrm{m})$ to allow comparisons between and within classes. Since the restriction was only based in total length and weight, all three groupings are multispecific.

Size and weight values were recalculated based on biological parameters of the species known lengthweight relationship (LWR) (Hansen 1986; García et al. 1998; Kohler et al. 1995; Mollet and Cailliet 1996; Frota et al. 2004; Vianna et al. 2004; Madureira and Rossi-Wongtschowski 2005; Motta et al. 2013; Puentes et al. 2014; Catelani et al. 2017; Costa et al. 2018). These calculations were then used to estimate the difference between what was reported by the interviewed fishers and what was expected based on length-weight relationships. Maximum known sizes for the reported species were obtained from the FishBase platform (Froese and Pauly 2019). Comparison between the recorded weights and lengths reported by artisanal fisher respondents and the recalculated values based on the LWR from the literature were made in order to evaluate differences for all fishes and the three size classes. Mean, median and standard deviation were calculated based on those differences (the reported and the calculated values) for each record. The differences are presented in percentage for weight (Dif.TW) and length (Dif.TL) with positive values when the reported weight/length is above the expected by LWR conversion and negative values when fishers underestimated the values of weight/length as indicated by the LWR conversion. Sell price obtained from fishers was converted to US Dollar (US\$), based on the exchange rate as in October $20^{\text {th }} 2021$.

\section{RESULTS}

\section{Artisanal fishers and fishing technology}

A total of 85 artisanal fishers from 39 to 83 years old from eight municipalities were interviewed, with an average age of $59.4( \pm 9.2)$, of which $70.6 \%$ are still active and the rest are retired. Fishing activity time ranged from 30 to 68 years, averaging 40.5 ( \pm 9.1$)$. Of this total, $35.3 \%$ were fishers with no fishing family tradition, $31.8 \%$ were fisher children, $14.1 \%$ represent the third fisher generation and $18.8 \%$ belong to ancient fisher lines associated to four or more generations (Figure 2). The sample was well distributed across the studied region, ranging from 16 interviews in Arraial do Cabo, São João da Barra and Campos dos Goytacazes each to three in Rio das Ostras, with an average of 10,6 fishers per location (Figure 3). Municipalities visited for the study also included Cabo Frio (11 fishers), São Francisco de Itabapoana (10 fishers), Macaé (8 fishers) and Armação dos Búzios (5 fishers). From this dataset, 81 interviews were used for further analysis, removing interviews from artisanal fishers under 40 in order to emphasize the information from the knowledge producers with the longest experience. The records reported by the fishers refer to catches obtained mainly by gillnets (48.1\%) and hooks and lines $(29.3 \%)$, also accompanied by an expressive use of bottom trawling (12.2\%). Longline $(4.8 \%)$ and traps $(5.7 \%)$ were also mentioned but were less important (Figure 3 ). The interviews recovered 253 events of noteworthy catches between 1960 to 2020, with a total combined capture of $637.2 \mathrm{t}$ of fish (average $=2.5 \mathrm{t}$, std. $\operatorname{dev} .=5.9 \mathrm{t}$, median $=1.0 \mathrm{t}$ ). Other 52 events could not be used for the temporal analysis because the precise date could not be provided. These catches considered memorable by fishers, while similar in number from the last two decades, reflected a decrease of $53.25 \%$ from 2001-2010 to 20112020 in total catch per record. (Table 1).

Artisanal fishers reported the capture of 58 fish categories treated under 69 common names, the most recurring being bonito-serra, Sarda sarda, sardines (Clupeidae), xerelete, Caranx spp, bonitos (Thunnini) and bluefish, Pomatomus saltatrix. Among these, common dolphinfish, red porgy and bluefish presented a total length reduction reported for records prior to 2009 and the last decade (Table 2). $M i$ cropogonias furnieri and Caranx spp, relevant local fisheries categories, exhibited mean length increases, although they were been reported in only some interviews.

\section{Weight and size estimates}

The estimated sizes provided by fishers showed deviations from the expected when compared to known length-weight relationship for each species. This difference, nonetheless, was not similar between different size classes of fishes. The accuracy of estimates for individuals between $30 \mathrm{~cm}$ and $1 \mathrm{~m}$ was higher than those above $1 \mathrm{~m}$ and below $30 \mathrm{~cm}$. Based on 90 catches, length reports differed from the expected by $11.3 \%$ $( \pm 30.2 \%)$. However, when grouped by size (TL> $1 \mathrm{~m}, 0.3 \mathrm{~m}<\mathrm{TL}<1 \mathrm{~m}$ and $\mathrm{TL}<0.3 \mathrm{~m})$, accuracy was greater in medium-sized fish from $0.3 \mathrm{~m}$ to 1 $\mathrm{m}$, underestimated by $13.5 \%( \pm 28.7 \%)$. Small individuals were overestimated by $18.0 \%$ ( $\pm 22.0 \%)$, and large individuals over $1 \mathrm{~m}$, underestimated by $22.4 \%$ $( \pm 27.1 \%)$. When the same analysis was applied to 


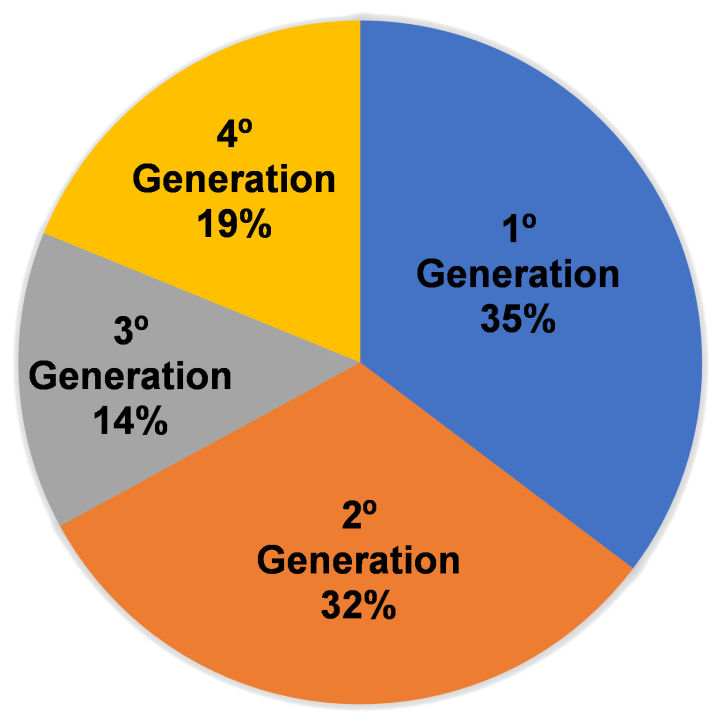

Figure 2. Percentage of artisanal fisher respondents dedicated to fishing in the Lakes Region and Northern Fluminense municipalities in the state of Rio de Janeiro, Brazil, categorized by family generation.

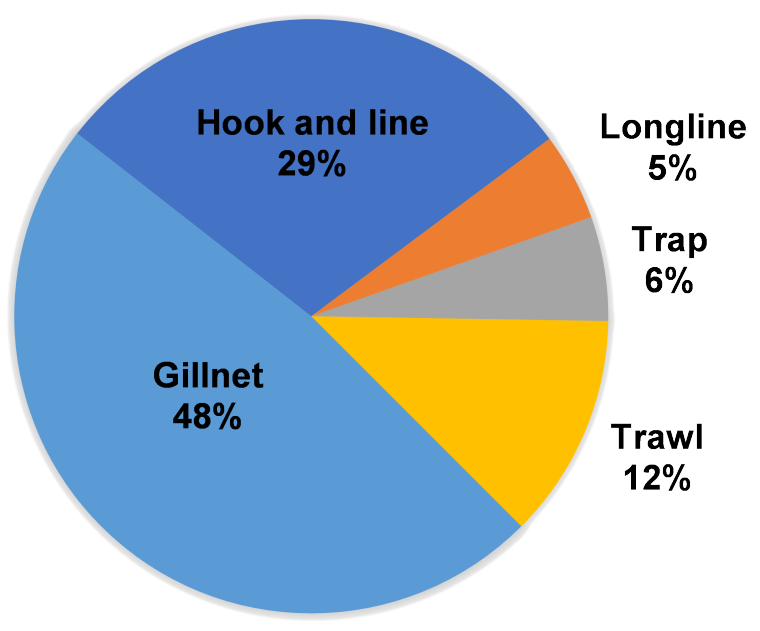

Figure 3. Records categorized by fishing gear reported by artisanal fisher respondents from the Lakes Region and Northern Fluminense municipalities in the state of Rio de Janeiro, Brazil.

weight estimates, reported data were more conflicting concerning what was reported and what was expected according to length-weight relationships, with a clear weight overestimation trend in relation to reported size noted. Based on 96 catches, weight reports were overestimated by $78.9 \%( \pm 151.1 \%)$, and as with size estimates, differences in accuracy were identified between weight ranges. Reports overestimated weights for fish with higher body masses $(>10 \mathrm{~kg}$ ) by $44.4 \%$ ( $\pm 139.3 \%)$. Weights were also overestimated for lighter fish $(<1 \mathrm{~kg})$, but with greater precision, by $30.1 \%( \pm 97.4 \%)$. The intermediate group $(1 \mathrm{~kg}<$ $\mathrm{TW}<10 \mathrm{~kg}$ ) presented the greatest distortions between reported and expected weights, overestimated by $112.7 \%$ ( $\pm 169.4 \%$ ) (Table 3$)$.

Two sets of species presenting ecological and economic importance, sharks and pescadas/pescadinhas, exhibited opposite behaviors. Sharks form a large group of Selachii where they are treated as a single group called cações. Although the artisanal fish- 
Table 1. Total production per records reported by artisanal fisher respondents from the Lakes Region and Northern Fluminense municipalities in the state of Rio de Janeiro, Brazil, grouped by decade.

\begin{tabular}{ccccc}
\hline \hline Decade & Total $(\mathrm{kg})$ & Records & Mean & Median \\
\hline \hline $\mathbf{1 9 8 1 - 1 9 9 0}$ & $134.486,0$ & 45 & $2.988,6$ & $1.150,0$ \\
$\mathbf{1 9 9 1 - 2 0 0 0}$ & $145.737,0$ & 62 & $2.350,6$ & $1.550,0$ \\
$\mathbf{2 0 0 1 - 2 0 1 0}$ & $221.343,0$ & 76 & $2.912,4$ & 700,0 \\
$\mathbf{2 0 1 1 - 2 0 2 0}$ & $103.472,7$ & 59 & $1.753,8$ & 700,0 \\
\hline \hline
\end{tabular}

Table 2. Mean total length variations reported by artisanal fisher respondents from the Lakes Region and Northern Fluminense municipalities in the state of Rio de Janeiro, Brazil, in records (maximum registries), prior to 2009 and in the last decade (2010-2020) and the national threat status (IUCN 2012; ICMBio 2018) for each species. The column "Records" represents the total number of records reported by fishers concerning each listed commercial category.

\begin{tabular}{ccccccc}
\hline \hline Category & Records & $\mathbf{1 9 6 0 - 2 0 0 9}$ & St.Dev. & 2010-2020 & St.Dev. & IUCN \\
\hline \hline Coryphaena hippurus & 9 & 125,0 & 25,0 & 55,7 & 11,7 & LC \\
Pomatomus saltatrix & 22 & 70,0 & 21,8 & 55,0 & 34,6 & LC $^{*}$ \\
Pagrus pagrus & 15 & 48,3 & 18,4 & 27,5 & 4,3 & LC \\
Balistes capriscus & 15 & 34,0 & 15,3 & 36,0 & 8,0 & LC $^{*}$ \\
Sarda sarda & 11 & 51,0 & 9,0 & 55,0 & 14,3 & LC \\
\hline \hline
\end{tabular}

* Considered vulnerable (VU) at the global threat level.

Table 3. Comparison between the record weights and lengths reported by artisanal fisher respondents from the Lakes Region and Northern Fluminense municipalities in the state of Rio de Janeiro, Brazil, and estimated values based on weight-length ratios. Fish are grouped by size (total length, TL, m) and weight (total weight, $\mathrm{TW}, \mathrm{kg}) . \mathrm{SD}=$ standard deviation.

\begin{tabular}{cccccccc}
\hline \hline All fishes (N=90) & Dif.TL (\%) & TL $>$ 1m & Dif.TL (\%) & 0,3m> TL $>$ 1m & Dif.TL (\%) & TL $<$ 0,3m & Dif.TL (\%) \\
\hline \hline Mean & $-11,3$ & Mean & $-22,4$ & Mean & $-13,5$ & Mean & 18,0 \\
Median & $-13,8$ & Median & $-18,6$ & Median & $-19,6$ & Median & 19,8 \\
St.Dev. & 30,2 & St.Dev. & 27,1 & St.Dev. & 28,7 & St.Dev. & 22,0 \\
\hline \hline All fishes (N=96) & Dif.TW (\%) & TW>10kg & Dif.TW (\%) & $\mathbf{1 k g}>$ TW $>$ 10kg & Dif.TW (\%) & TW $<\mathbf{1 k g}$ & Dif.TW (\%) \\
\hline \hline Mean & 78,9 & Mean & 44,4 & Mean & 112,7 & Mean & 30,1 \\
Median & 24,6 & Median & 3,5 & Median & 57,8 & Median & $-0,4$ \\
St.Dev. & 151,1 & St.Dev. & 121,9 & St.Dev. & 169,4 & St.Dev. & 97,4 \\
\hline \hline
\end{tabular}

ers are able to identify species and smaller groups such as hammerhead sharks (Sphyrna spp.), tiger shark (Galeocerdo cuvier) and mako shark (Isurus oxyrinchus), among others, this group is treated as grouped for one or some fishing landing categories. Pescadas/pescadinhas reflect a diverse group of Sciaenidae species displaying similar morphology, mostly comprising Cynoscion and Macrodon (Santos and Vianna, 2017). The catches informed by artisanal fishers indicate a reduction of events of sharks captured in records $(60.4 \%)$, while the total weight recorded on these events also showed a decline over time $(62.4 \%)$. Concerning pescadas/pescadinhas, the comparison between the last 20 years and the previous two decades indicated a $36.5 \%$ reduction in the total landed volume on record, with a similar drop (35.7\%) in the number of occurrences (Table 4). Large catch events in the last two decades for shrimp, another relevant and historical resource in the study region, also decreased, both for landed volume $(78.2 \%)$ and number of events $(63.2 \%)$. In comparison, bluefish, also a typical monospecific resource, displayed a $63.2 \%$ decrease in the landed total of record catches, even though the number of events in the last two decades 
Table 4. Temporal variations for sharks, pescadas/pescadinhas, bluefish and shrimp category records reported by artisanal fisher respondents from the Lakes Region and Northern Fluminense municipalities in the state of Rio de Janeiro, Brazil.

\begin{tabular}{cccc}
\hline \hline Category & Period & Records & Total capture $(\mathrm{kg})$ \\
\hline \hline Sharks & $1961-1980$ & 2 & $\mathbf{1 3 0 0 , 0}$ \\
& $1981-2000$ & 15 & $\mathbf{2 2 2 4 2 , 0}$ \\
& $2001-2020$ & 6 & $\mathbf{8 3 7 0 , 0}$ \\
Shrimps & $1961-1980$ & 2 & $\mathbf{4 0 0 0 , 0}$ \\
& $1981-2000$ & 19 & $\mathbf{1 7 7 4 0 , 0}$ \\
& $2001-2020$ & 7 & $\mathbf{5 4 6 0 , 0}$ \\
Bluefish & $1961-1980$ & 1 & $\mathbf{1 2 0 0 0 , 0}$ \\
& $1981-2000$ & 8 & $\mathbf{2 2 7 4 0 , 0}$ \\
& $2001-2020$ & 10 & $\mathbf{8 3 6 7 , 0}$ \\
\hline Pescadas/pescadinhas & $1961-1980$ & 2 & $\mathbf{1 7 0 0 , 0}$ \\
& $1981-2000$ & 14 & $\mathbf{1 1 3 5 0 , 0}$ \\
& $2001-2020$ & 9 & $\mathbf{7 2 1 0 , 7}$ \\
\hline \hline
\end{tabular}

was higher $(25 \%)$ than that reported for the previous two decades (Table 3 ).

\section{Ethno-names and historical records}

A total of 69 ethno-names used by fishers, including variations, were identified herein, associated with 58 fish categories. Of this total, the names were associated to 57 local ichthyofauna species or genera, while one could not be linked to any taxonomic identification. In addition to the ethno-names associated with sharks and pescadas/pescadinhas, the use of seven other ethno-names was also observed, including nonspecific fish or crustacean groupings, as in the cases of sardines (sardinhas, Clupeidae), anchovies (manjubas, Engraulidae), groupers (garoupas, Epinephelinae), bonitos (Thunninae), prawns (camarões, Penaeidae), octopuses (polvos, Octopodidae) and squids (lulas, Loliginidae). Thirteen ethnonames were used for Selachii species, ranging from generic names, such as sharks, to specific ones such as whale shark, Rhincodon typus. Elasmobranchs also presented multiple designations for the same species, such as for Galeocerdo cuvier (marimbondo, tubarão-tigre, tintureira) and Carcharodon carcharias (tubarão-branco, anequim-boto). Although shark and cação are equivalent designations, Selachii are predominantly treated under the same name. Teleosts were categorized by the greatest diversity of ethnonames, reflecting their diversity in the study area ecosystems. Bony fishes also represented the main source of species included in non-specific groupings, such as the large number of species cited as sardines, anchovies and groupers, as well as the aforementioned pescadas/pescadinhas. The three main commercially exploited crustaceans (Artemesia longinaris, Xiphopenaeus kroyeri and Farfantepenaeus spp.) were also mentioned by the artisanal fisher respondents (Table 5).

This study allowed for the retrieval and addition of two more records of the presence of the white shark Carcharodon carcharias in Brazilian waters (Figure 4), previously reported as rarely occurring on the Atlantic coast of South America (Gadig and Rosa 1996; Cione and Barla 2008; Amorim et al. 2018), but confirmed by the fisher survey concerning records, containing both information and photographic evidence. The oldest account, concerning the capture of a $C$. carcharias in 1968 , was reported by a 76 -year-old fisher who reported a size of $11 \mathrm{~m}$ and 6 ton. The preservation of the photographic record of this capture allowed for confirmation of the species' occurrence and was also used to correct the fisher's size estimate. Length was obtained based on fin size, indicating a $5.3 \mathrm{~m}$ specimen with an estimated weight of 2.2 ton. Other records were indicated by artisanal fishers and reported in this study, such as the occurrence of the tiger shark Galeocerdo cuvier, comprising four reported catches, with specimens ranging from 20 to $360 \mathrm{~kg}$ (161 to $393 \mathrm{~cm} \mathrm{TL}$ ) TL), indicating the 

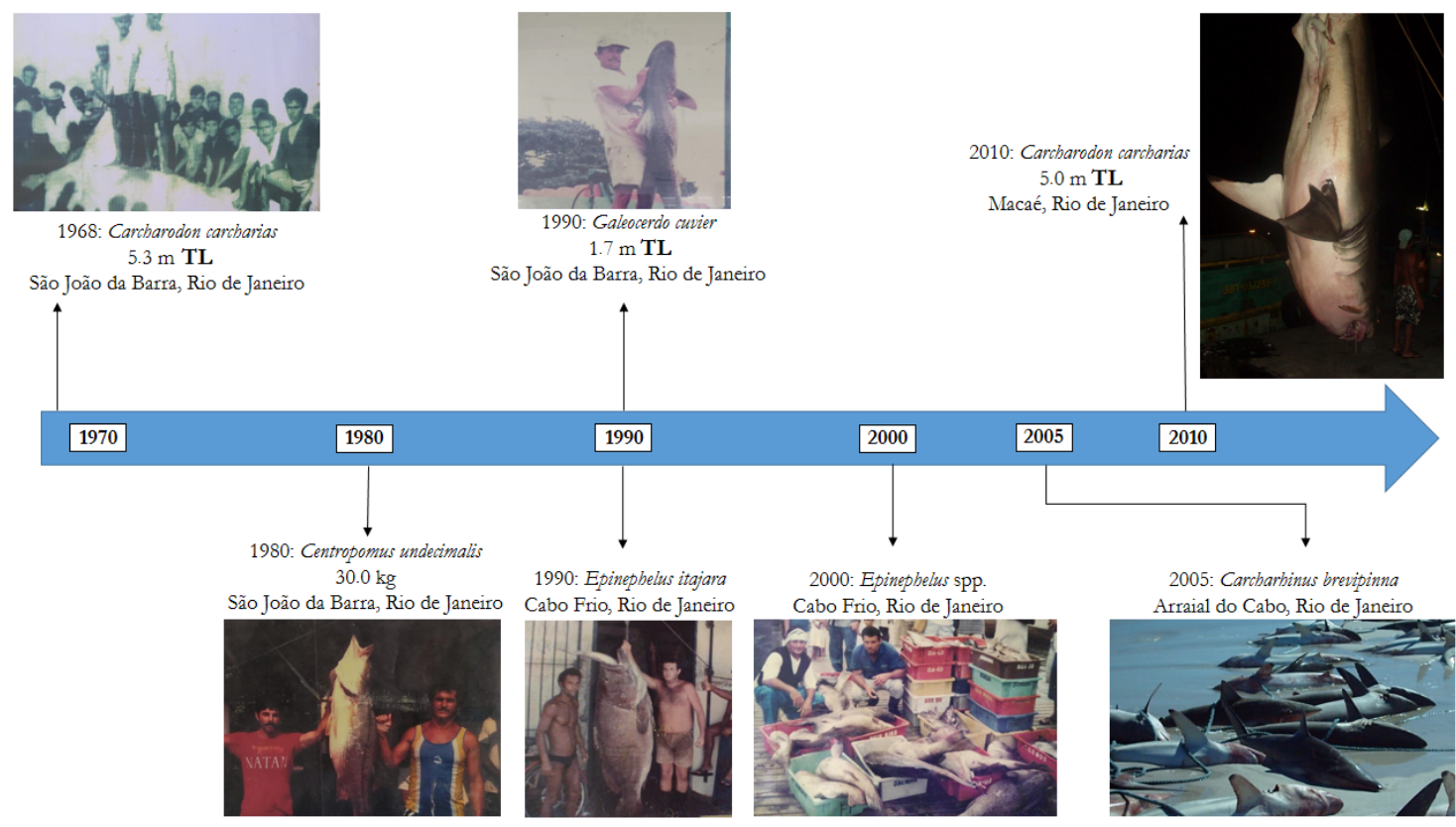

.

Figure 4. Photographic accounts of record catches provided by artisanal fisher respondents from the Lakes Region and Northern Fluminense municipalities in the state of Rio de Janeiro, Brazil, for the last 50 years.

presence of both juvenile and adult individuals in the region, proven by a 1990 photographic record. As with the individual records, the data retrieval carried out herein was also informative concerning large catches with regard to production volume, notably the beach seine fishing of a considerable number of spinner sharks Carcharhinus brevipinna in Arraial do Cabo, in 2005. A report on the capture of a common snook specimen, Centropomus undecimalis, which may be the largest record for the species, was also obtained. The reported weight for the captured specimen was of $30 \mathrm{~kg}$, which potentially represents an individual with about $1.5 \mathrm{~m} \mathrm{TL}$. This is larger than the records reported for this genus in Brazil (1.13 m TL) and in the rest of the Western Atlantic (24.3 kg) (IGFA 2019).

\section{Fisher perceptions and the Shifting Baseline Syndrome}

The fishers were asked about alterations in the biological communities that sustain their fishing activities, in order to assess the most important fish categories for artisanal fisheries and fishers. The fishers were free to give their opinion on all fish they wished to report. The following question comprises three main axis: A perception of abundance and size alterations, fish that disappeared over a long period of time and fish recently becoming the most captured. Based on 85 interviews, 221 perceptions of fishers were obtained for relevant fishery categories in the study region.
Ninety-six percent of records $(n=204)$ reported by the fishers described a scenario of population decline of commercial species in the region, while most fishers did not report any perceived change in total length through time for the categories they remembered $(57 \%)$ (Figure 5). Fishers attributed the observed impacts to increased fishing pressures (59\%), but also consider area use conflicts as relevant (19\%). Pollution was identified as responsible in $7 \%$ of the stories (Figure 6). The fishers reported the effects of decreased abundance and/or size on various fish categories, the most recurrent comprising bluefish, tiger shark, shrimps, largehead hairtail (espada, Trichiurus lepturus) and grey triggerfish (peruá, Balistes capriscus). This was reinforced when they mentioned the "disappearance" of these species over time. This removal does not necessarily means the local extinction of a species but the depletion of the fishing stock to a point where an incidental catch might occur but will not provoke or sustain an increase of fishing effort. On the other hand, categories that recently began displaying higher fish landing importance comprised a diverse group of current artisanal fishing targets mentioned by fishers, such as shrimp, red porgy, pescadas/pescadinhas, Jamaica weakfish (goete, Cynoscion jamaicensis), jacks and sardines. Pelagic species such as mackerel and common dolphinfish are also included, as well as categories mentioned as declining, like grey triggerfish and bluefish. Change perceptions were also distinguished by age groups ( $<55$ years old, $55-65$ years old, $>65$ years old $)$ and 


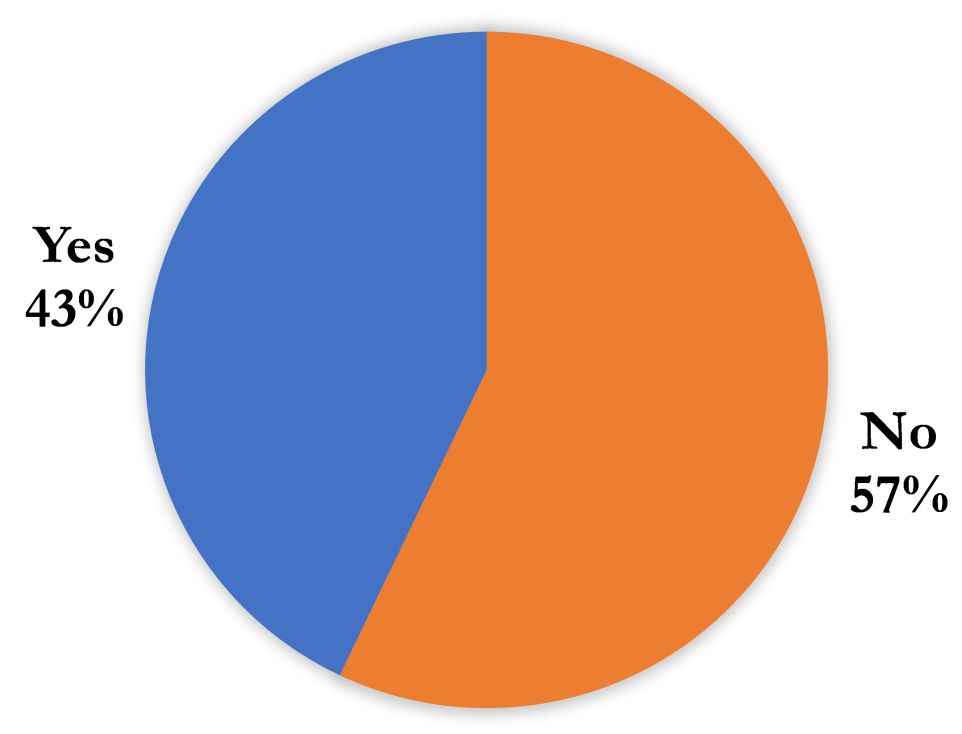

Figure 5. Perception of artisanal fishers regarding ecosystem changes in Lakes Region and Northern Fluminense municipalities in the state of Rio de Janeiro, Brazil, when asked if decreases in fish sizes exploited in the region have occurred.

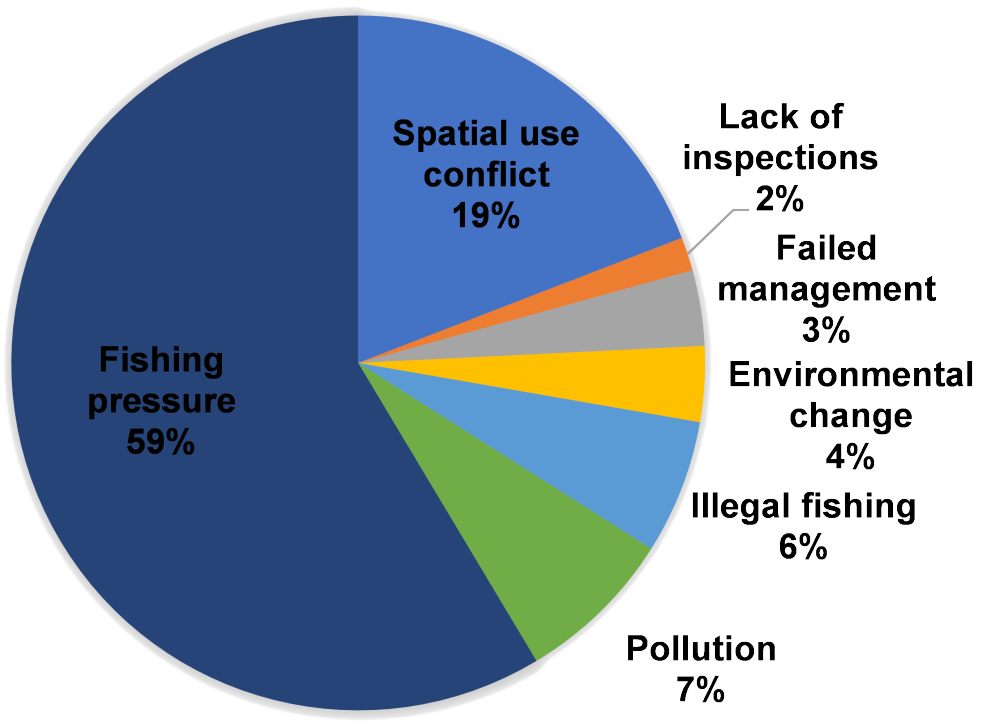

Figure 6. Perception of artisanal fishers concerning ecosystem changes in in Lakes Region and Northern Fluminense municipalities in the state of Rio de Janeiro, Brazil, when asked what are the causes for the decreases in the abundance/size of the fish populations exploited in the study region.

allowed for the identification of an impasse concerning the observation of fish population size changes, although the prevailing trend in the 55-65 class was to consider that no noticeable changes have taken place (Figure 7). In the case of captured biomass, the scenario of commercial species population declines was clearly described by fishers from all age groups, with
193 out of 201 reports pointing to decreased catches for several categories (Figure 7). 

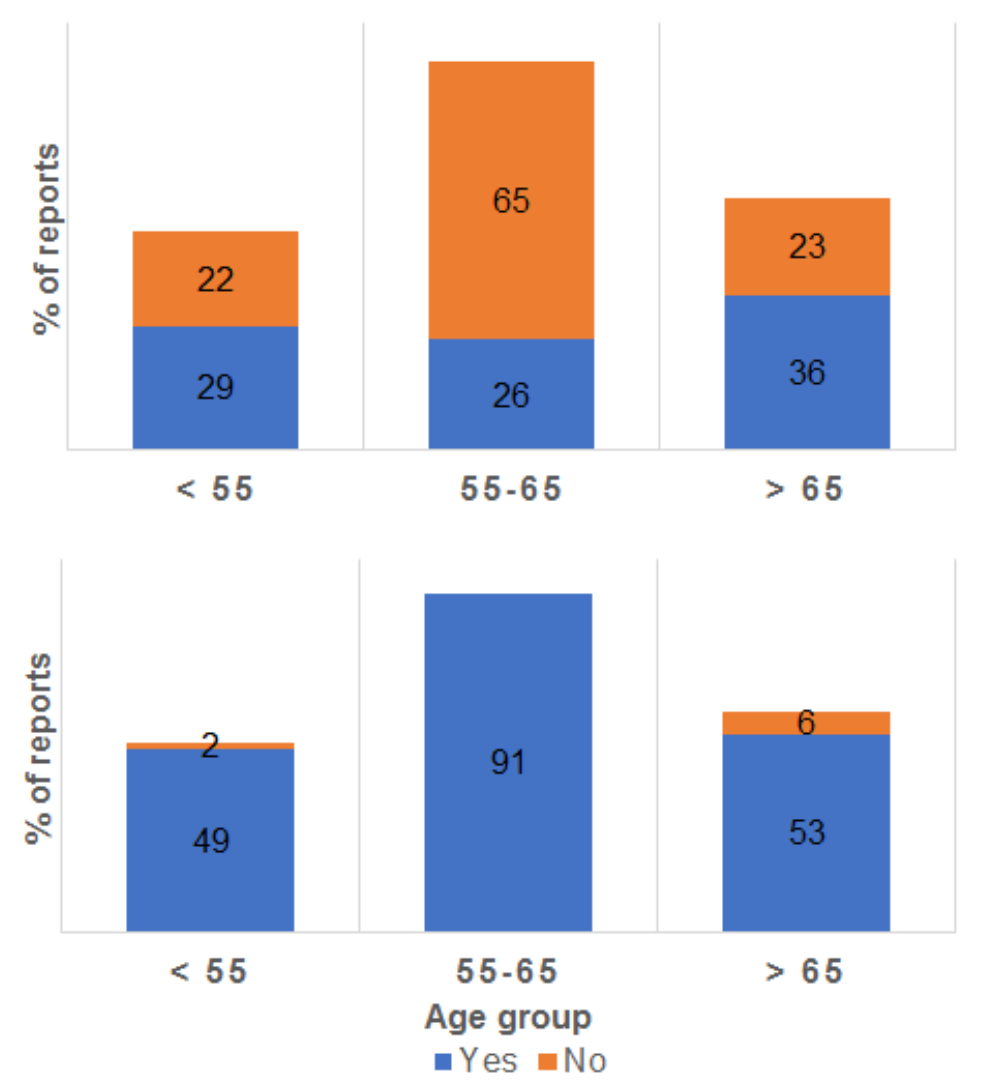

Figure 7. Fisher perceptions concerning changes in (A) fish abundance and (B) fish size declines regarding the commercial fishes reported for the Lakes Region and Northern Fluminense municipalities in the state of Rio de Janeiro, Brazil.

\section{DISCUSSION}

\section{Artisanal fishers and fishing technology}

The approach to traditional knowledge in a marine ecosystem context is a relatively recent and rapidly expanding theme, requiring investments in a collaborative structure that unites researchers, managers and fishers, aiming to integrate empirical and scientific knowledge (Thornton and Scheer 2012; Abreu et al. 2017). The interviewed fishers demonstrated that most professionals comprise first- or secondgeneration fishers. In a previous study, Bender et al. (2014) pointed out the occurrence of the shifting baseline syndrome (SBS) in interviews with fishers from Arraial do Cabo, Rio de Janeiro, indicating species removals and biomass losses in several commercial categories, including sharks and groupers. The SBS exposes not only long-term losses of the reference of collective knowledge on environmental changes, but it also involves another even more damaging loss in the context of traditional communities. Traditional knowledge demands that new generations be trained by previous generations to minimize the loss of acquired knowledge. Thus, when the SBS translates into composition and biomass changes, the loss of traditional knowledge also instills a loss concerning the ability to recognize the local fauna, which makes it impossible for changes in these components to be perceived by subsequent generations.

Catch volumes do not establish a direct relationship with the local fisheries production scale, but it is acceptable that commercial species biomass reductions provide fewer opportunities for large catches by fishers. The present study demonstrated that captured volume and the number of recorded events have decreased in the last three decades. Bender et al. (2014) also pointed out fish stock declines in the region, based not only on the analysis of catches comprising different items following fisher interviews in Arraial do Cabo, but also on the observation of fish abundance by a visual census and fisheries production data. The interviews with reports of records through the use of different fishing gears, although mainly nets and lines, suggest that a similar scenario reported by Bender et al. (2014) has been present in the region 
for the past 30 years, also corroborating a scenario of declining environmental health in the region and its ichthyofauna and decreases in certain fish sizes as cited by the fisher respondents, such as bluefish, $P$. saltatrix, red porgy P. pagrus and dolphinfish C. hippurus. This suggests that the stocks of these species are under great fishing pressure. It is important to note that all reports are based on interviews with artisanal fishers, although the same resources are shared with industrial fisheries, even comprising a point of conflict between both fisheries. However, the initial records remembered by the oldest fishers already reflect the presence of a nascent industrial fleet whose presence in the region started in the 1960s and expanded in the following decades (Ritter and Galheigo 2009).

\section{Weight and size estimates}

Accurate data concerning estimated fish sizes and weights are extremely important for the use of these values as a complement to official data of past fishing activities and productions. This potential is even greater considering the historical gaps concerning knowledge on commercial species and small-scale fishing activities (Begossi et al. 2016). When the estimated values were compared to length-weight relationships, it was noted that the fishers reported values close to the expected in the case of size, especially for medium-sized fish. Although the variation was considerable for both the aggregated records and analyzed size classes, the difference averaged less than $12 \%$. This demonstrates the feasibility of obtaining fishing data and stock conditions based on fisher memories. Even if it is not possible to replace these data with those generated by continuous fishing activity monitoring efforts, an indispensable practice for sustainable fisheries management, they do allow for a punctual reference to the most cited fish categories of a given community or region as reported by artisanal fishers. The observed distortion concerning blennid Salarias fasciatus estimates was evaluated by St. John et al. (1990) based on dive data obtained in Australia. The authors compared the estimates of expert divers and recorded an average size accuracy of $86 \%$ compared to biologist estimates. Accuracy was slightly higher than the average for all fish cited by artisanal fishers, which can be credited to the fact that divers were usually focused on only one species. In addition, another important aspect raised by St. John et al. (1990) is that observer bias can over- or underestimate fish within a certain size range. This aids in understanding the high standard deviation values presented herein concerning the size class average differences, ranging from $22 \%$ for fish smaller than 30 $\mathrm{cm}$ to $28.7 \%$ for fish between $30 \mathrm{~cm}$ and $1 \mathrm{~m}$.
The reliability of size estimates by experts was also compared to that of lay observers for Carcharodon carcharias (May et al. 2019), with experienced scientists displaying higher accuracy than the lay public. The experience and constancy with which the fish are observed and identified is essential to the quality of reported size records. In this context, the accuracy of experienced fishers is closer to that reported by scientists compared to the lay public, with greater precision observed for large commercial interesting fish, as identified in the present study. Concerning weight, the lower accuracy for all weight ranges was also noted for fishers. This suggests less confidence in the use of these data, with average differences of over $79 \%$ and high variations. Given the clear data deficit for Brazilian fisheries, which still lack accurate and continuing fisheries statistics, the opportunity to recover data on past fishery stock conditions based on size estimates cannot be overlooked, even more so when taking into account the precision displayed by the interviewed fishers.

\section{Ethno-names and historical records}

The use of common names in fishing activity monitoring in Brazil is a known problem concerning data quality and the correct determination of fishing efforts to which exploited species are subjected to (Freire and Pauly 2005). The problem is even greater in the context of the names used in artisanal fishing practices, where the isolation of fishing communities allows for the development of a characteristic language, including ethno-names used to name the most common or most interesting fishing species (Santos and Vianna 2017; Marques et al. 2019). In a survey conducted by Freire and Pauly (2005) based on official data from Brazilian fisheries monitoring efforts, the ethno-name cação was used for 20 shark species. Pescadas/pescadinhas are ethno-names associated with 13 species, basically Sciaenidae, but also Sphyraena (Sphyraenidae) species (Freire and Pauly 2005; Santos and Vianna 2017). Barbosa-Filho et al. (2021), based on interviews with fishers from northeastern Brazil, reported an average of 4.8 ethno-names per shark species, indicating that such a wealth of names makes it impossible to monitor fishing landings at the specific level if it is not performed alongside specialist fishers from the monitored region. Despite fewer names reported, the same recommendation stated by Barbosa-Filho et al. (2021) applies to the present study. Name richness, however, is not random and names apply anatomical, ontogenetic, ecological or behavioral references, which open the opportunity to take advantage of ethnoknowledge to improve monitored data. This suggestion, also made by Barbosa-Filho et al. (2021), must consider the ethnoknowledge from dif- 
ferent fisher generations from the same community, as well as differences between communities. The interviews carried out herein in the studied region revealed distinct ethno-names for the same species, such as for the tiger shark Galeocerdo cuvier, also called tintureira and marimbondo. The variety of ethnonames has taken hold in nearby communities in the last 30 years, demonstrating that different names can coexist without the predominance of only one form.

The use of the names pescadas and pescadinhas is exemplary to demonstrate the complexity of ethnonames and the limits of their use by the academy and by fishing effort monitoring bodies. The main family associated with this ethno-name, Sciaenidae, is one of the most important in commercial Brazilian fishing. Concerning this family, the ethno-name pescadas and pescadinhas encompasses the highest number of species, applied to both the marine forms of Cynoscion and Macrodon, as well as freshwater Pachyurus, Plagioscion and Pachypops. Furthermore, other Sciaenidae species are also associated with the name, such as Isopisthus parvipinnis, more commonly associated with the ethno-name faneca, and Nebris microps, known as pescada-rolão, pescada-banana or pescada-rosa (Santos and Vianna 2017). The difficulties encountered for pescadas and pescadinhas are also repeated for other Brazilian fishing landing categories, such as flounders. The continued use of these ethnonames in fisheries statistics without proper taxonomic identification represents a major obstacle to the use of official landing data, with consequences already identified regarding the scientific production pace on the biology and fishing of these species (Santos and Vianna 2017; Santos and Vianna 2018). Pescadas and pescadinhas are also applied to distinct groups such as species belonging to the Sphyraena (Sphyraenidae) genus, which are commonly known as barracudas. In addition, cultural traces of a Portuguese origin still remain in fishing communities in Brazil, which is particularly important in the state Rio de Janeiro, one of the oldest Portuguese colonization sites in the Americas. The pescada ethno-name, applied to Merluccius (Merluccidae) on the Portuguese coast, is also used by fishers from the coast of Rio de Janeiro, cited as Portuguese hake (pescada-portuguesa) for Merluccius hubbsi, although this species is more commonly known in Brazil as merluza (Santos and Vianna 2017).

The ethno-names pescadas and pescadinhas were relevant in the present study, mentioned in 27 reports, but only thirteen included weight and size estimates. Even so, that these ethno-names may be applied as a reference to the size of captured specimens, being relatively independent of species. Thus, the same species may be treated as pescadas or pescadinhas, depending on the size range limit interpreted by the fisher. Although arbitrary, the collected data point to both a weight limit, where all individuals less than $1 \mathrm{~kg}$ were associated with pescadinha, and a size limit, with shapes smaller than $40 \mathrm{~cm}$ also mentioned as pescadinha. As a consequence of this reasoning, specific size limitations may acquire a certain degree of taxonomic precision. Acoupa weakfish (pescadaamarela) Cynoscion acoupa adults, that reach over 1 $\mathrm{m}$ in length, would not be described as pescadinha, only in their young forms, but all Isopisthus parvipinnis individuals would be treated as faneca or associated with pescadinha, since the species does not reach $40 \mathrm{~cm}$. Ethno-names applied to different sizes are also recurrent in other fish groups, as described by Ferreira-Araújo et al. (2021) for small pelagics from northeastern Brazil, treated as ginga or sardines. The authors report that the first ethno-name is basically associated with Clupeidae individuals smaller than 7 $\mathrm{cm}$, while specimens larger than $10 \mathrm{~cm}$ were cited by fishers as sardines. More interviews are required to validate the values indicated by the data obtained herein, and it is necessary to verify how much personal variations displace these limits within a fishing community, while also evaluating intergenerational ethnoknowledge changes.

The white shark $C$. carcharias is an emblematic species in the popular imagination, rare in Brazilian waters and with only a few dozen occurrences recorded along the coast, with Rio de Janeiro being the northernmost area of South American occurrences (Gadig and Rosa 1996; Cione and Barla 2008). The oldest record reported by fishers was from 1968, with the specimen being called an anequim-boto, followed by another more recent incident, in 2010. Gadig and Rosa (1996) indicate the occurrence of this species in Rio de Janeiro due to a local seasonal upwelling phenomenon.

The present study allowed for the understanding of several ethnoknowledge aspects and its potential as a source of data and as a contributor to the understanding of regional fisheries. Records, past data and criteria that permeate the ethno-taxonomy of the fishing communities allow us to observe and understand periods not considered in academic studies or in official data. Despite supporting fisheries statistics, ethno-names lack taxonomic specificity for several groups, and fishers may contribute to resolve inconsistencies between popular and scientific knowledge. The nomenclatural complexities observed for sharks or pescadas/pescadinhas require attention, as these groups display economic interest and/or are under a certain degree of threat. While ethno-names are of interest as capture records, they also reflect knowledge on species biology. Despite the focus on size or landed volume records, many of the species listed herein are categorized by more than one ethno-name. However, unlike the representation of regional or in- 
tergenerational variations, ethno-names may identify ontogenetic phases. Conversely, the use of ethnoknowledge also indicates the need for attention concerning the validation and selection of the reported knowledge. In addition to differences regarding current ethno-names, that display regional and intergenerational variations, weight and size estimates reported by fishers were characterized by significant deviations from what was expected, although demonstrating greater average accuracy than expected for the lay public. These estimates may be indicative of the state of fishery stocks at the time, but do not replace technical data produced by government agencies or academic studies.

\section{Fisher perceptions and the Shifting Baseline Syndrome}

The perception of elasmobranch population losses was well marked in the fisher reports obtained herein, addressing a wide variety of sharks, but particularly the tintureira, G. cuvier. This was the most mentioned species and its decline is attributed primarily to fishing impacts from both industrial and predatory fishing, although the deleterious effects of pollution were not forgotten. Martins et al. (2018) evaluated fishing practices and the value chain associated with shark captures and concluded that, although fishers recognize declining elasmobranch populations, they rarely act to conserve and maintain their stocks. This observation also applies to artisanal fishers in the Lakes Region and Northern Fluminense study area, although the responsibility attributed to overfishing is also accompanied by the claim that the impact generated by industrial fisheries is much greater than artisanal fisheries effects. Ignorance regarding environmental legislation was also mentioned in the study carried out in northeastern Brazil (Martins et al. 2018) and was confirmed in the Lakes Region and Northern Fluminense study area. Despite the existence of regulation currently in effect (MPA/MMA 2012), resources obtained with non-selective fishing gears, such as gillnets, responsible for the capture of most elasmobranchs, are difficult to monitor due to deficiency in inspection.

In an ethnoecological survey on artisanal shark fishing in the Brazilian state of Bahia, Barbosa-Filho et al. (2021) indicated a great shark meat appreciation by the local population. Their field activities developed with fishers, consumers and employees from the fishing value chain indicate that the same is valid for the Lakes Region and Northern Fluminense areas, as low prices facilitate the access of small traders and lower-income populations to these fish. It is important to note that Barbosa-Filho et al. (2019) also pointed out a preference for smaller sharks mea- suring less than $1 \mathrm{~m}$, indicating a predilection for juvenile individuals, corroborated by the difference in prices applied for individuals in this size range (US\$ 1.07 to US\$ 3.58) and for those larger than 1 $\mathrm{m}$ (US\$ 0.54 to US\$ 1.43). When cross-referencing the data obtained for current fishing practices in the Lakes Region and Northern Fluminense areas with fisher reports, the results indicate that most current shark captures and consumption refer primarily to the sharpnose sharks Rhizoprionodon lalandii and $R$. porosus, smaller species usually measuring with less than $1 \mathrm{~m}$ when caught.

The interviews carried out herein indicate that over $10 \%$ of the reports concerning fish abundance and size decreases refer to sharks, especially G. cuvier, a large shark that can reach over $7 \mathrm{~m}$ and 800 kg (Froese and Pauly 2019; IGFA 2019), comprising more than $40 \%$ of elasmobranch reports. The case of the study area points to the possibility that the preference for sizes smaller than $1 \mathrm{~m}$ compromises the recovery capacity of populations of large fish species, such as G. cuvier, but also includes other sharks such as hammerhead sharks Sphyrna spp., spinner sharks Carcharhinus brevipinna and thresher shark Alopias spp., as also reported by Barbosa-Filho et al. (2019). The current situation regarding the predominance of the landing of smaller species, such as Rhizoprionodon spp. may reflect the loss or declines of large shark populations in the region over the past 70 years.

Fishers also pointed out biomass and size decreases for sardines in the Lakes Region and Northern Fluminense areas. Ethnoknowledge assessments were applied by Braga et al. (2018), in Arraial do Cabo, who verified a wide understanding regarding reproduction, diet, behavior, trophic interactions and habitat. Fisher interviews indicated a historic loss of sardine landings, especially the Brazilian sardinella, Sardinella brasiliensis, attributed to excessive fishing pressures by industrial fleets. Studies indicate that, despite the declines in $S$. brasiliensis stocks reported by fishers, following a national collapse (Freire et al. 2015), sardine supplies are still maintained, supported by the Atlantic thread herring Opisthonema oglinum. This point is of special ecological interest, as small pelagic foragers comprise an essential trophic web link concerning energy transfers from the lower levels (plankton) to higher ones (medium and large predators) and significant knowledge gaps for their effective management are still noted (Peck et al. 2021). The continuous decline of these populations can cause a cascade effect including other resources that depend on this food item, with potential negative consequences for fisheries production and the associated value chain, as already pointed out in a simulation performed by Vasconcellos and Gasalla (2001).

Marine spatial planning is still under development 
in Brazil. Local experiences are consistent, but a governmental structure or forums for debates among the various actors involved in marine space use are still lacking (Gerhardinger et al. 2019; Borges et al. 2020). Several of the interviewed fishers reported conflicts concerning the use of fishing areas and oil activities, either due to the presence of vessels at the service of exploration companies or the production facilities that began to occupy the local landscape in the last 70 years. Other impacts pointed out as responsible by fishers can also be partly and indirectly associated with the development of local oil exploration, such as increased light and noise pollution, removing stocks from areas previously considered as fishing areas by traditional communities. This negative interaction was pointed out for several important local resources, such as pelagic bluefish, demersal grey triggerfish, benthopelagic largehead hairtail and the shrimp Farfantepenaeus brasiliensis (camarão-rosa), suggesting that these impacts reach several trophic levels and different habitats.

The survey carried out herein also evaluated increased local fisheries production resources, comprising the mention of new resources, either distinct or scarcely mentioned when fishers were questioned concerning declining resources over time. The dynamics of species exchanges brings up the discussion of the concept of "fishing down marine food webs" proposed by Pauly et al. (1998). This process can be described as continuous population losses of higher trophic level species, which potentiate trophic web collapses due to the absence of predators, as well as increasing the populations of originally predated species that end up becoming the only available resources for local fisheries and reflect decreases in average trophic levels of local fisheries productions. A marked decline concerning sharks was noted for both size and in biomass by local fishers, most noteworthy for the tintureira (tiger shark), G. cuvier, but also for bluefish, shrimps, Brazilian sardinella and grey triggerfish. The history of fishing landings in the study area demonstrates that, although top predators have been exploited, more important resources such as Brazilian sardinella and grey triggerfish have also suffered intense fishing pressures, resulting in the collapse of these resources, even though they are not high trophic level species (Vianna et al. 2007; Freire et al. 2015). The presence of an upwelling system at Arraial do Cabo (Coelho-Souza et al. 2012) and a coastal conformation that brings together the oceanic environments of the coast (Viana et al. 1998) are also relevant for the analysis and for the local trophic web, providing a unique Brazilian coast environment, increasing primary production and, consequently, the presence of small pelagic and large predators, including oceanic species. This point was supported by the fisher interview results, as bonito (Thunnini), mackerel (Scomberomorus cavalla) and common dolphinfish (Coryphaena hippurus), all medium and large migratory pelagic fish, both coastal and oceanic, were identified as resources with catches extended over time. Furthermore, increased bonito and mackerel productions were attributed to the appreciation of these species, and in the case of the latter, due to the fact that it served as a substitute due to the decline of another pelagic species, bluefish.

\section{CONCLUSION}

The use of traditional knowledge as a tool for the historical retrieval of fisheries information was proven valid, but some care is required in the validation of this information. Science is built by a continuous evidence and knowledge accumulation process, and scientists always attempt to work with the best information available. However, empirical knowledge is an interpretation of reality based on personal experiences and, therefore, susceptible to different truths. Consequently, the use of scientific evidence associated with traditional knowledge is a very promising means to fill temporal gaps.

The research, through the access of the collective memory of artisanal fishers, showed a complex scenario that described changes in fishes targeted by commercial fisheries. Furthermore, the study was able to determine the usefulness of incorporating this source of information to solve some of the knowledge gaps that hinders the development of effective management plans. Nonetheless, this must be done with extreme care and must be compared to and validated by the current knowledge for each species in order to eliminate bias from the fishers viewpoint.

\section{ACKNOWLEDGEMENT}

This study was supported by a compensatory measure established by the Conduct Adjustment Term under the responsibility of PetroRio, conducted by the Federal Public Ministry - MPF/RJ, with the implementation of the Brazilian Fund for Biodiversity - Funbio and the Pescarte Environmental Education Project, which is a mitigation measure required by the Federal Environmental Licensing, conducted by IBAMA. The authors would like to thank Maurício D. Abreu for the 2010 Carcharodon carcharias photograph, Dr. Rachel Ann Hauser-Davis for translating the manuscript and the fishers who participated in the survey by answering the questionnaire. 


\section{DATA AVAILABILITY}

The data used to support the findings of this study are available from the corresponding author upon reasonable request.

\section{CONFLICT OF INTEREST}

The authors have no conflicts of interest to declare.

\section{CONTRIBUTION STATEMENT}

Conceived of the presented idea: SRBS, MLCM, TRM, GBGS, MV.

Carried out the interviews: MLCM, LSA.

Carried out the data analysis: SRBS, GBGS, MV. Wrote the first draft of the manuscript: SRBS, MLCM, TRM, GBGS, LSA, OBFG, MV.

Reviewed and wrote the final draft of the manuscript: SRBS, MLCM, TRM, GBGS, LSA, OBFG, MV.

Supervision: MV.

\section{REFERENCES}

Abreu JS, Domit C, Zappes CA (2017) Is there dialogue between researchers and traditional community members? The importance of integration between traditional knowledge and scientific knowledge to coastal management. Ocean \& Coastal Management doi: 10.1016/j.ocecoaman.2017.03.003.

Amorim AF, Arfelli CA, Bornatowski H, Hussey NE (2018) Rare giants? A large female great white shark caught in Brazilian waters. Marine Biodiversity doi: 10.1007/s12526-017-0656-9.

Barbosa-Filho MLV, Ramires M, Mourão JS, Rosa RS, Alves RRN, Costa-Neto EM (2021) Ethnotaxonomy of sharks by fishers from south Bahia, Brazil: Implications for fisheries management and conservation. Ethnobiology and Conservation doi: 10.15451/ec2021-08-10.02-1-12.

Barbosa-Filho MLV, Souza GBG, Lopes SF, Siciliano S, Hauser-Davis RA, Mourão JS (2020) Evidence of shifting baseline and fisher judgement on lane snapper (Lutjanus synagris) management in a Brazilian marine protected area. Ocean \& Coastal Management doi: 10.1016/j.ocecoaman.2019.105025.

Begossi A, Salivonchyk S, Lopes PFM, Silvano RAM (2016) Fishers' knowledge on the coast of Brazil. Journal of Ethnobiology and Ethnomedicine doi: 10.1186/s13002-016-0091-1.
Bender MG, Machado GR, Silva PJdA, Floeter SR, Monteiro-Netto C, Luiz OJ, Ferreira CEL (2014) Local Ecological Knowledge and Scientific Data Reveal Overexploitation by Multigear Artisanal Fisheries in the Southwestern Atlantic. PLoS ONE doi: 10.1371/journal.pone.0110332.

Bernardes LMC, Bernardes N (1950) A pesca no litoral do Rio de Janeiro. Revista Brasileira de Geografia 12:17-53.

Blythe JL, Murray G, Flaherty MS (2013) Historical perspectives and recent trend in the coastal Mozambican fishery. Ecology and Society doi: 10.5751/ES-05759-180465.

Borges R, Eyzaguirre I, Barboza RSL, Glaser M (2020) Systematic review of spatial planning and marine protected areas: A Brazilian perspective. Fronteirs in Marine Science doi: 10.3389 /fmars.2020.00499.

Braga HO, Pardal MA, Cruz RCM, Alvarenga TC, Azeiteiro UM (2018) Fishers' knowledge in Southeast Brazil: The case study of the Brazilian sardine. Ocean and Coastal Management doi: 10.1016/j.ocecoaman.2018.08.021.

Braga HO, Pardal MA, Musiello-Fernandes J, Azeiteiro UM (2020) Target species of artisanal fisheries and their conservation status in two fishing villages in the Atlantic: Peniche (Portugal) and Arraial do Cabo (Brazil). Ethnoscientia doi: 10.22276/ethnoscientia.v5i1.322.

Canty S, Funes M, Box S, Zylich K, Derrick B, Divovich E, Lindop A, Pauly D, Zeller D (2019) The hidden value of artisanal fisheries in Honduras. Fisheries Management and Ecology doi: $10.1111 /$ fme. 12346 .

Catelani PA, Bauer AB, Petry AC (2017) Lengthweight relationships of fishes from the estuary of the Macaé River, Southeastern Brazil. Journal of Applied Ichthyology doi: 10.1111/jai.13443.

Cione AL, Barla MJ (2008) Causes and contrasts in current and past distribution of the white shark (Lamniformes: Carcharodon carcharias) off southeastern South America. Revista del Museo Argentino de Ciencias Naturales 10:175-184.

Coelho-Souza SA, López MS, Guimarães JRD, Coutinho R, Candella RN (2012) Biophysical interactions in the Cabo Frio upwelling system, southeastern Brazil. Brazilian Journal of Oceanography doi: 10.1590/S1679-87592012000300008.

Costa MR, Tubino RA, Monteiro-Neto C (2018) Length-based estimates of growth parameters 
and mortality rates of fish populations from a coastal zone in the Southeastern Brazil. Zoologia doi: $10.3897 /$ zoologia.35.e22235.

Essington TE, Beaudreau AH, Wiedenmann J (2006) Fishing through marine food webs. PNAS doi: 10.1073/pnas.0510964103.

Ferreira-Araújo T, Lopes PFM, Lima SMQ (2021) Size matters: identity of culturally important herrings in northeastern Brazil. Ethnobiology and Conservation doi: 10.15451/ec2020-11-10.07-130 .

Foley CMR (2013) Management implications of fishing up, down, or through the marine food web. Marine Policy doi: 10.1016/j.marpol.2012.04.016.

Freire KMF, Pauly D (2005) Richness of common names of Brazilian marine fishes and its effect on catch statistics. Journal of Ethnobiology doi: 10.2993/0278-0771(2005)25[279:ROCNOB]2.0.CO;2..

Freire KMF, Aragão JAN, Araújo ARR, Ávila-daSilva AO, Bispo MCS, Velasco G, Carneiro MH, Gonçalves FDS, Keunecke KA, Mendonça JT, Moro PS, Motta FS, Olavo G, Pezzuto PR, Santana RF, Santos RA, Trindade-Santos I, Vasconcelos JA, Vianna M, Divovich E (2015) Reconstruction of catch statistics for Brazilian marine waters (1950-2010). Fisheries Centre Research Reports 23: $3-29$.

Froese R, Pauly D (eds) (2019) FishBase. World Wide Web electronic publication. [Www. fishbase.org] Accessed December 2020.

Frota LO, Costa PAS, Braga AC (2004) Lengthweight relationships of marine fishes from the central Brazilian coast. NAGA WorldFish Center Quarterly 27: 20-26.

Gadig OBF, Rosa RS (1996) Occurrence and distribution of the white shark, Carcharodon carcharias, in Brazilian waters. In: Klimley PA, Ainley DG (eds) Biology of White Shark. Academic Press, San Diego, pp. 347-350.

García CB, Duarte JO, Sandoval N, von Schiller D, Melo G, Navajas P (1998) Length-weight relationships of demersal fishes from the Gulf of Salamanca, Colombia. NAGA WorldFish Center Quarterly 21: 30-32.

Gerhardinger LC, Quesada-Silva M, Gonçalves LR, Turra A (2019) Unveiling the genesis of a marine spatial planning arena in Brazil. Ocean and Coastal Management doi: 10.1016/j.ocecoaman.2019.104825.
Giglio VJ, Luiz OJ, Gerhardinger LC (2015) Depletion of marine megafauna and shifting baselines among artisanal fishers in eastern Brazil. Animal Conservation doi: 10.1111/acv.12178.

Grønmo S (2020) Social Research Methods: Qualitative, quantitative and mixed methods approaches. SAGE Publications Ltd.

Hansen JE (1986) Aspectos biológicos y pesqueros del bonito del Mar Argentino [Pisces, Scombridae, Sarda sarda]. PhD Thesis, Universidad Nacional de La Plata, Buenos Aires, Argentina.

IBGE - Instituto Brasileiro de Geografia e Estatística (2010) Censo de 2010. [www.ibge. gov.br/home/estatistica/populacao/censo2010/ default.shtm] Accessed 20 janeiro 2021.

ICMBio-MMA (2018) Livro vermelho da fauna brasileira ameaçada de extinção: Volume VI - Peixes. First edition. Brasília, D.F. 4162pp.

IGFA - International Game Fish Association (2019) 2019 World Record Game Fishes. IGFA, Flórida, EUA. 444pp.

IUCN - International Union for Conservation of Nature (2012) IUCN Red List categories and criteria: Version 3.1. Second edition. IUCN Gland, Switzerland and Cambridge, UK. 36pp.

Kohler NE, Casey JG, Turner PA (1995) Lengthweight relationships for 13 species of sharks from the western North Atlantic. Fishery Bulletin 93:412-418.

Ladislau DS, Souza PL, Aride PHR, Oliveira AT, Gubiani ÉA (2021) Current situation and future perspectives of ethnoichthyology in Brazil. Ethnobiology and Conservation doi: 10.15451/ec2020-1110.09-1-35.

Lopes MS, Bertucci TCP, Rapagnã L, Tubino RA, Monteiro-Neto C, Tomas ARG, Tenório MC, Lima T, Souza R, Carrillo-Briceño JD, Haimovici M, Macario K, Carvalho C, Aguilera-Socorro O (2016) The Path towards Endangered Species: Prehistoric Fisheries in Southeastern Brazil. PLoS ONE doi: 10.1371/journal.pone.0154476.

Madureira LSP, Rossi-Wongtschowski CLDB (eds.). (2005) Prospecção de recursos pesqueiros pelágicos na Zona Econômica Exclusiva da Região Sudeste-Sul do Brasil: hidroacústica e biomassas. Série documentos Revizee: Score Sul, Instituto Oceanográfico, USP, São Paulo, Brazil. 144 p.

Marques RA, Julio TG, Sole-Cava AM, Vianna M (2019) A new strategy proposal to monitor ray 
fins landings in south-east Brazil. Aquatic Conservation: Marine and Freshwater Ecosystems doi: 10.1002 /aqc.3203.

Martins APB, Feitosa LM, Lessa RP, Almeida ZS, Heupel M, Silva WM, Tchaicka L, Nunes JLS (2018) Analysis of the supply chain and conservation status of sharks (Elasmobranchii: Superorder Selachimorpha) based on fisher knowledge. PLoS ONE doi: 10.1371/journal.pone.0193969.

May C, Meyer L, Whitmarsh S, Huveneers C (2019) Eyes on the size: accuracy of visual length estimates of white sharks, Carcharodon carcharias. Royal Society Open Science 6:190456.

MPA (Ministério da Pesca e Aquacultura) /MMA (Ministério do Meio Ambiente) (2012) Instrução Normativa Interministerial $\mathrm{N} \mathbf{0}_{12}$, de 22 de agosto de 2012. Diário Oficial da União.

Mollet HE, Cailliet GM (1996) Using allometry to predict body mass from linear measurements of the white shark. In: Klimley AP, Ainley DG (eds) Great white sharks. The biology of Carcharodon carcharias. Academic Press, Inc., San Diego, pp. 81-90.

Motta FS, Caltabellotta FP, Namora RC, Gadig OBF (2013) Length-weight relationships of sharks caught by artisanal fisheries from southeastern Brazil. Journal of Applied Ichthyology doi: 10.1111/jai.12234.

Pauly D (1995) Anecdotes and the shifting baseline syndrome of fisheries. Trends in Ecology and Evolution doi: 10.1016/s0169-5347(00)89171-5.

Pauly D, Christensen V, Dalsgaard J, Froese R, Torres Jr. F (1998) Fishing down marine food webs. Science doi: 10.1126/science.279.5352.860.

Peck MA, Alheit J, Bertrand A, Catalán IA, Garrido S, Moyano M, Rykaczewski $\mathrm{RR}$, Takasuka A, van der Lingen CD (2021) Small pelagic fish in the new millennium: A bottom-up view of global research effort. Progress in Oceanography doi: $10.1016 /$ j.pocean.2020.102494.

Pinnegar JK, Engelhard GH (2008) The shifting baseline phenomenon: a global perspective. Reviews in Fish Biology Fisheries doi: 10.1007/s11160-007-9058-6.

Prestrelo L, Oliveira R,Vianna M (2019) A new proposal to classify small fishing vessels to improve tropical estuarine fishery management. Fisheries Research doi: 10.1016/j.fishres.2018.11.010.

Prestrelo L, Vianna M (2016) Identifying multiple-use conflicts prior to marine spa- tial planning: A case study of a multilegislative estuary in Brazil. Marine Policy doi: 10.1016/j.marpol.2016.02.001.

Puentes V, Escobar FD, Polo CJ, Alonso JC (eds) (2014) Estado de los principales recursos pesqueros de Colombia - 2014. Serie Recursos Pesqueros de Colombia. Oficina e Generación del Conocimiento y la Información/AUNAP, Bogotá, Colombia, 244p.

Ritter P, Galheigo FA (2009) Pesca fluminense: História, sociologia e perspectivas In: Diagnóstico da cadeia produtiva da pesca marítima no Estado do Rio de Janeiro: relatório de pesquisa. FAERJ:SEBRAE-RJ, Rio de Janeiro, pp. 13-46.

Saldaña-Ruiz LE, Sosa-Nishizaki O, Cartamil D (2017) Historical reconstruction of Gulf of California shark fishery landings and species composition, 1939-2014, in a datapoor fishery context. Fisheries Research doi: 10.1016/j.fishres.2017.07.011.

Santos SR, Vianna M (2017) Scientometric Analysis of the Fisheries Science for the Species of Cynoscion (Sciaenidae: Perciformes) from the Western Atlantic, with Emphasis in the Comparison of the North American and Brazilian Fisheries Catch Data. Reviews in Fisheries Science \& Aquaculture doi: 10.1080/23308249.2017.1337078.

Soga M, Gaston KJ (2018) Shifting baseline syndrome: causes, consequences, and implications. Frontiers in Ecology and the Environment doi: $10.1002 /$ fee. 1794 .

St. John J, Russ GR, Gladstone W (1990) Accuracy and bias of visual estimates of numbers, size structure and biomass of a coral reef fish. Marine Ecology Progress Series doi: 10.3354/meps064253.

Santos SR, Vianna M (2018) Scientometric Analysis of Fisheries Science Studies of Western Atlantic Species of Paralichthys (Paralichthyidae: Pleuronectiformes). Reviews in Fisheries Science \& Aquaculture doi: 10.1080/23308249.2018.1452896.

Silva-Júnior LC, Andrade AC, Vianna M (2008) Caracterização de uma pescaria de pequena escala em uma área de importância ecológica para elasmobrânquios, no Recreio dos Bandeirantes, Rio de Janeiro. Arquivos de Ciências do Mar 41:47-57.

Thornton TF, Scheer AM (2012) Collaborative Engagement of Local and Traditional Knowledge and Science in Marine Environments: A Review. Ecology and Society doi: 10.5751/ES-04714- 
170308.

Vasconcellos M, Gasalla MA (2001) Fisheries catches and the carrying capacity of marine ecosystems in southern Brazil. Fisheries Research doi: 10.1016/S0165-7836(00)00217-4.

Viana AR, Faugeres JC, Kowsmann RO, Lima JAM, Caddah LFG, Rizzo JG (1998) Hydrology, morphology and sedimentology of the Campos continental margin, offshore Brazil. Sedimentary Geology doi: 10.1016/S0037-0738(97)00090-0.

Vianna M, Costa FES, Ferreira CN (2004) Lengthweight relationship of fish caught as by-catch by shrimp fishery in the southeastern coast of
Brazil. Boletim do Instituto de Pesca 30:81-85.

Vianna M, Rodrigues AMT, Lin CF (2007) Descrição da pescaria de peroá (Balistes capriscus) com a utilização do puçá-grande no sudeste do Brasil. Boletim do Instituto de Pesca $33: 229-236$.

Received: 24 May 2021

Accepted: 22 November 2021

Published: 27 January 2022

Editor: Rômulo Alves 
Table 5. List of ethno-names reported by artisanal fisher respondents from the Lakes Region and Northern Fluminense municipalities in the state of Rio de Janeiro, Brazil, alongside their closest taxonomic correspondence.

\begin{tabular}{|c|c|}
\hline Categories & Species \\
\hline \multicolumn{2}{|l|}{ Specific identified groupings } \\
\hline Teleostei & 39 \\
\hline raquete & Aluterus monoceros \\
\hline salema & Parona signata \\
\hline peruá & Balistes capriscus \\
\hline xerelete, graçainha & Caranx crysos, $C$. latus \\
\hline xaréu & Caranx hippos \\
\hline robalo & Centropomus spp. \\
\hline roncador & Conodon nobilis \\
\hline dourado & Coryphaena hippurus \\
\hline maria-mole & Cynoscion guatucupa \\
\hline goete & Cynoscion jamaicensis \\
\hline pescada, escamuda & Cynoscion spp. \\
\hline marimbá & Diplodus argenteus \\
\hline mero & Epinephelus itajara \\
\hline garoupa-verdadeira & Epinephelus marginatus \\
\hline cherne & Hyporthodus niveatus \\
\hline baiacú & Lagocephalus spp. \\
\hline prejereba & Lobotes surinamensis \\
\hline peixe-sapo & Lophius gastrophysus \\
\hline vermelho & Lutjanus spp. \\
\hline corvina, corvinota & Micropogonias furnieri \\
\hline tainha & Mugil liza \\
\hline badejo, badejo-saltão & Mycteroperca spp. \\
\hline guaivira & Oligoplites spp. \\
\hline pargo & Pagrus pagrus \\
\hline maria-luisa & Paralonchurus brasiliensis \\
\hline solteira & Parona signata \\
\hline enchova & Pomatomus saltatrix \\
\hline olho-de-cão, mirassol & Priacanthus arenatus \\
\hline namorado & Pseudopercis numida \\
\hline sarda, serra & Sarda sarda \\
\hline cavalinha & Scomber colias \\
\hline cavala & Scomberomorus cavalla \\
\hline galo & Selene spp. \\
\hline olhete & Seriola lalandii \\
\hline barracuda & Sphyraena barracuda \\
\hline bicuda & Sphyraena guachancho \\
\hline cabeça-dura & Stellifer spp. \\
\hline pampo & Trachinotus carolinus \\
\hline espada & Trichiurus lepturus \\
\hline Crustacea & 3 \\
\hline camarão-barba-ruça & Artemesia longinaris \\
\hline camarão-rosa & Farfantepenaeus spp., Pleoticus muelleri \\
\hline camarão-sete-barbas & Xiphopenaeus kroyeri \\
\hline Elasmobranchii & 6 \\
\hline $\begin{array}{l}\text { cação-corre-costa } \\
\text { tubarão-branco, anequim-boto }\end{array}$ & $\begin{array}{l}\text { Carcharhinus brevipinna, Rhizoprionodon spp. } \\
\text { Carcharodon carcharias }\end{array}$ \\
\hline
\end{tabular}


cação-marimbondo, cação-tigre, tintureira cação-niquim

cação-baleia

cação-martelo

Multispecies groupings
polvo
cação-areia, cação-olho-azul, caçã
troce, cação, cação-tubarão, tubarão
bonito

bonito

pescadinha

camarão

lula

manjuba

sardinha

garoupa

Non-identified categories

totonho
Galeocerdo cuvier

Isurus oxyrinchus

Rhincodon typus

Sphyrna spp.

Octopodidae

Selachii

Thunnini

Sciaenidae

Penaeidae

Loliginidae

Engraulidae

Clupeidae

Epinephelinae 